\title{
Erratum to: The Harvest and Management of Migratory Bird Eggs by Inuit in Nunatsiavut, Labrador
}

\author{
David Natcher · Larry Felt $\cdot$ Keith Chaulk • \\ Andrea Procter
}

Published online: 9 October 2012

(c) Springer Science+Business Media New York 2012

\section{Erratum to: Environmental Management DOI 10.1007/s00267-012-9939-x}

Following the review of the online version of this paper, it was felt by the authors that additional clarification was required on two important points.

First, in the section on Anthropogenic Disturbance (paragraph two, sentence two), it is more accurate to say that these effects include interrupted staging (i.e., fright and flight), stress, and in some cases, nest abandonment.

Second, in the section addressing Cultural Norms (column two, paragraph one), it is more accurate to say that eggs that float tend to have more trapped gases, thereby contributing to increased buoyancy.

Last, there were two errors in referencing. The first is found in the section on Biophysical Factors (column two, paragraph one) where Chaulk and Roberts 2004 is cited.
The correct reference is Chaulk and others (2004) and the correct bibliographic reference is

Chaulk KG, Robertson GJ, Montevecchi WA (2004)

Regional and annual variability in common eider nesting ecology in Labrador. Polar Res 23(2):121-130.

The second error, found in the sections on Biophysical Factors (first paragraph) and Anthropogenic Disturbances (first paragraph), is Williams (1997). This reference should read Williamson (1997) and the correct bibliographical reference is

Williamson T (1997) From sina to sikujaluk: our footprints. Mapping Inuit environmental knowledge in the Nain district of Northern Labrador. Report prepared for the Labrador Inuit Association. Nain, Labrador.

The online version of the original article can be found under doi:10.1007/s00267-012-9939-x.

D. Natcher $(\square)$

Indigenous Land Management Institute, University

of Saskatchewan, 51 Campus Drive, Room 2D08,

Saskatoon, SK S7N 5A8, Canada

e-mail: david.natcher@usask.ca

L. Felt

Department of Sociology, Memorial University, St. John's,

NF, Canada

K. Chaulk

Labrador Institute, Memorial University, St. John's, NF, Canada

A. Procter

Department of Anthropology, Memorial University, St. John's,

NF, Canada 